\title{
Recovery of Copper and Cobalt from Converter Slag with a New Flotation Method Using $\mathrm{H}_{2} \mathrm{~S}$
}

\author{
Ibrahim Tegin $^{1}$ and Recep Ziyadanoğulları ${ }^{2}$ \\ 1. Department of Chemistry, Faculty of Science and Art, Siirt University, Siirt 56100, Turkey \\ 2. Departmentof Chemistry, Faculty of Science, Dicle University, Diyarbakır 21280, Turkey
}

\begin{abstract}
In this study, two different samples were obtained from Küre Copper factory. It was determined that the samples contain: the sample of K.C.F. (Küre Copper Factory), $0.70 \% \mathrm{Cu}$ and $0.5 \% \mathrm{Co}$. This sample was firstly grounded at -100 mesh dimension. Flotation was done according to previously obtained optimum flotation conditions. The flotation yield of $\mathrm{Cu}$ and $\mathrm{Co}$ in concentrate phase was found to be low by collective flotation. Even when the samples were grounded at -160 mesh, no change was observed in the flotation result. Especially, Co could not float under the flotation conditions of the non-sulfurized samples. There, a new flotation method was applied which was not applied until now. For this aim, the samples were firstly sulphurised under the steam of $\mathrm{H}_{2} \mathrm{~S}+\mathrm{H}_{2} \mathrm{O}$. By this method, the amount of $\mathrm{Cu}$ and $\mathrm{Co}$ in the samples get rich. According to the obtained results, the optimum reactions for flotation and sulphurization were determined. In the first sulphurization conditions for the sample of K.C.F., the yield of flotation for the Co and Co were found to be $98.27 \%$ and $68.07 \%$, respectively. The results indicate that $\mathrm{Cu}$ can be floated at low yield in the original samples. On the other hand, Co cannot float under these conditions.
\end{abstract}

Key words: Converter slag, flotation, copper, cobalt, sulphurization.

\section{Introduction}

Copper slag is produced in large amounts in seven copper smelter plants in Chile, and it is estimated that around 4 million tons of slag are disposed every year and another 40 to 45 million tons are historically cumulated [1]. Different slags need aid transformed as by-products clinched alongside metallurgical methods alternately as residues on incineration methods. As stated by the sources and the characteristics, those fundamental slags might be ordered under three categories, in particular, ferrous slag, non-ferrous slag furthermore incineration slag. Slags generally hold numerous amount of profitable metals. They would really be an auxiliary asset from claiming metals, instead of an end-waste, what's more, they would be connected as an asset material in numerous zones. Clinched alongside addition, to a portion application,

Corresponding author: Ibrahim Tegin, Ph.D., main research fields: preconcentration, flotation and solid phase extraction. slags bring tantamount alternately indeed better properties over their focused materials. The third characteristic may be that some slags hold an outstanding amount of hurtful alternately overwhelming metals. Those discharge about these metals might cause natural issues $[2,3]$.

Metallurgical strategies would as a rule used to treat ores, what's more, of the enriching procedure by flotation strategies, are attractive division. A past article accounted that floatation what's more, attractive detachment methods, utilizing slag, didn't bring about acceptable extractions starting with converter slag [4].

Much exploration needs to be been conveyed out on the recuperation of copper from slags. Suggested strategies for cleaning the slag are flotation $[5,6]$, leaching, electric heater and so on [7].

Copper smelting techniques may be used [5, 8-11]. There are also some hydrometallurgical methods given in the literature for the treatment of slags, such as leaching in nitrate, perchloride, chlorate and 
sulfuric acids $[12,13]$ with and without pressure [13], ferric chloride [8, 14, 15], ferric sulfate [7], cyanide, thiosulphate leaching [16], ferric sulfate and ammonia sulfate solutions $[7,12,17,18]$.

In this study, the flotation of converter slag was attempted. When this was unsuccessful, a sulfurization process developed in the previous studies was used. As a result of this process, a new surface forms on the converter slag particles and flotation experiments were carried out using these samples [19-21]. As seen in the previous studies, successful results cannot be obtained by direct flotation of the original converter slag. However, in this study, significant results were obtained by flotation of a sample obtained from an appropriate sulfurization process.

\section{Experimental}

\subsection{Reagents and Instrumentation}

In this study, the converter slag used was supplied from the Kastamonu-Küre, Turkey. Küre is in the Western Black Sea region of Turkey, are a leading copper and pyrite ore production area. Analyses show that the ore obtained from the Küre Region contains
$0.70 \%$ copper, $0.50 \%$ cobalt and $21.98 \%$ sulfur. The K-Amyl xanthate and Dowfroth 250 used in flotation were taken from the Ergani Copper Mining Co in Turkey. The chemicals used in these studies such as $96 \%$ (w/v) $\mathrm{H}_{2} \mathrm{SO}_{4}, 37 \%$ (w/v) $\mathrm{HCl}, 65 \%$ (w/v) $\mathrm{HNO}_{3}$, $\mathrm{FeS}$ and $\mathrm{KClO}_{3}$ were purchased from Merck. The sample crushing was broken in a crusher belonging to Unal Engineering as -100 mesh size. The experiments were conducted in a laboratory equipped with facilities for carrying out hydrometallurgical operations such as autoclave leaching. Denver mark flotation apparatus and $\mathrm{Nel} 890$ Model $\mathrm{pH}$ meter were used for flotation and determination of $\mathrm{pH}$ of samples, respectively. Sulfur in various forms was oxidized to sulfate form and precipitated as $\mathrm{BaSO}_{4}$ and the precipitate with fixed weighing was analyzed by gravimetric method [22]. The compositions of all samples were determined using a Unicam 929 Model AAS. The spectral wavelength selected for the metal analyses is shown in Table 1.

In this study, the solutions used were prepared with concentrations of 25-100 ppm for copper and 20-60 ppm for cobalt. Calculation of flotation yield was made according to Eq. (1).

$$
\text { F. Y. } \%=\frac{\text { Amount of substance required to float in Floating Substance }}{\text { The total amount of substance required }} \times 100
$$

\subsection{Method}

The converter slag sample was first crushed and then ground to -100 mesh sizes, sieved and dried at $110{ }^{\circ} \mathrm{C}$. These samples were used in chemical analyses and flotation studies. $\mathrm{H}_{2} \mathrm{~S}$ was produced by addition of $\mathrm{H}_{2} \mathrm{SO}_{4}$ to $\mathrm{FeS}[6,21]$ obtained from pyrite. The sulfurization process was performed in an autoclave of 1.3-liter internal volume, with 60 minutes residence time at $100{ }^{\circ} \mathrm{C}$. Different ratios of a gas mixture of $\mathrm{H}_{2} \mathrm{~S}+\mathrm{H}_{2} \mathrm{O}$ were performed. Then, samples obtained from autoclave were floated by using potassium amyl xanthate and Dowfroth 250. After the obtained concentrates and wastes are solubilized with acid, analyzes are read in AAS.

\section{Results and Discussion}

\subsection{Effect of pH on the Flotation of Converter Slag}

Converter slag sample was floated at different $\mathrm{pHs}$ and the results are given in Fig. 1 [21].

This study was carried out under the conditions indicated in Table 2.

As seen in Fig. 1, the best flotation yield was at $\mathrm{pH}$ 11.0 .

For flotation, $100 \mathrm{~g}$ of the ore sample was fed and $28.56 \mathrm{~g}$ of converter slag was floated. The flotation yields of $\mathrm{Cu}$ and $\mathrm{Co}$ were determined as $57.81 \%$ and 
Table 1 The spectral wavelength of metal for AAS.

\begin{tabular}{lllll}
\hline Metal & Wavelength $(\mathrm{nm})$ & Silit $(\mathrm{nm})$ & Current $(\mathrm{mA})$ & Oxidant-Fuel \\
\hline Copper & 324.75 & 0.5 & 3 & Air-Acetylene \\
Cobalt & 240.73 & 0.2 & 10 & Air-Acetylene \\
\hline
\end{tabular}

Table 2 Flotation condition at different pHs.

\begin{tabular}{ll}
\hline Parameter & Flotation condition \\
\hline Particle dimension & -100 mesh \\
Solid/liquid ratio & $100 \mathrm{~g} / \mathrm{L}$ \\
Collector & $0.2 \mathrm{~g} \mathrm{Z}(\mathrm{KAX}) 3$ minute mix \\
Frother & $0.5 \mathrm{~mL}$ Dowfroth $250(1 \%) 2$ minute mix \\
Mix speed & 900 periods/minute \\
Flotation time & 3 minute \\
\hline
\end{tabular}

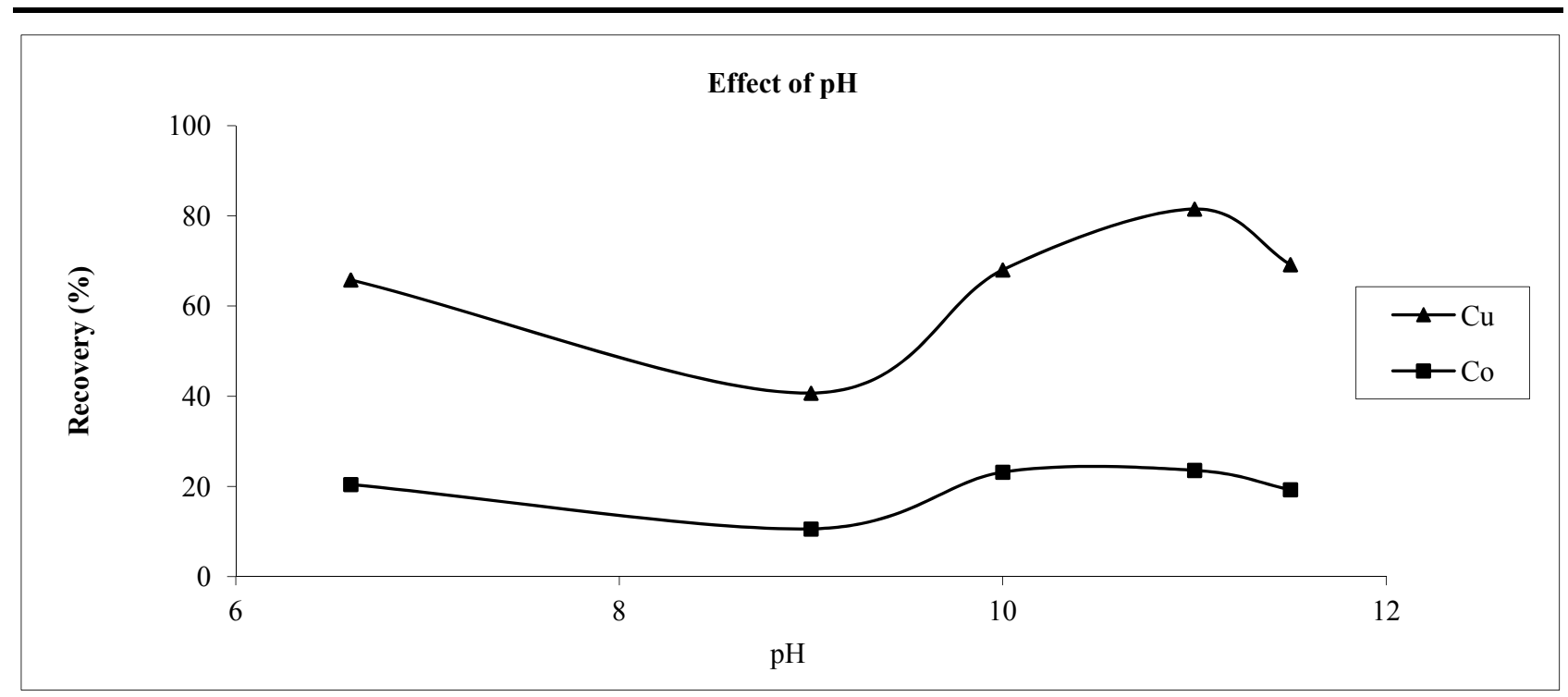

Fig. 1 The effect of $\mathrm{pH}$ on the flotation yield.

$34.38 \%$ respectively, and their concentrate grades of $\mathrm{Cu}$ and $\mathrm{Co}$ have ascertained as $1.17 \%$ and $0.43 \% \mathrm{Co}$. At the end of the flotation process, the results aimed were not attained, and flotation yield was low. Converter slag samples were first sulfurized at $100{ }^{\circ} \mathrm{C}$ by using various ratios of $\mathrm{H}_{2} \mathrm{~S}+\mathrm{H}_{2} \mathrm{O}$. Then, these samples were floated.

\subsection{The Flotation of Sulfurized Converter Slag}

Firstly, the converter slag samples were ground, sieved to -100 mesh size, dried at $110^{\circ} \mathrm{C}$ and then reacted with gas mixtures containing different amounts of $\mathrm{H}_{2} \mathrm{~S}+\mathrm{H}_{2} \mathrm{O}$ for 1 hour at $100{ }^{\circ} \mathrm{C}$. For this purpose, the six samples each of which was $1000 \mathrm{~g}$, were reacted with mixtures of $\mathrm{H}_{2} \mathrm{~S}$ and $\mathrm{H}_{2} \mathrm{O}$ separately as seen in Table 3.

After sulfurization, the sulfurized samples were floated at $\mathrm{pH} 11$ under the conditions indicated in Table 2 .

Eight sulfurized sample was floated at different sulfurization condition and the results are given in Fig. 2 and Table 4.

As seen in Table 4, the best result was obtained from a seventh sulfurized sample by flotation. In order to be understood better these results; they are given in Fig. 2 with respect to different $\mathrm{H}_{2} \mathrm{~S}$ values.

\subsection{The Effect of the Activator}

In this step, the flotation process on the seventh sulfurized sample was performed to test the effect of 
Table 3 The used amount of gas mixtures of $\mathrm{H}_{2} \mathrm{~S}$ and $\mathrm{H}_{2} \mathrm{O}$.

\begin{tabular}{lll}
\hline Sulphurization number & $\mathrm{H}_{2} \mathrm{~S}$ amount $(\mathrm{g})$ & Water amount $(\mathrm{g})$ \\
\hline 1 & 3.83 & 20 \\
2 & 5.74 & 30 \\
3 & 7.66 & 40 \\
4 & 9.57 & 50 \\
5 & 13.40 & 70 \\
6 & 15.32 & 80 \\
7 & 17.23 & 90 \\
8 & 19.14 & 100 \\
\hline
\end{tabular}

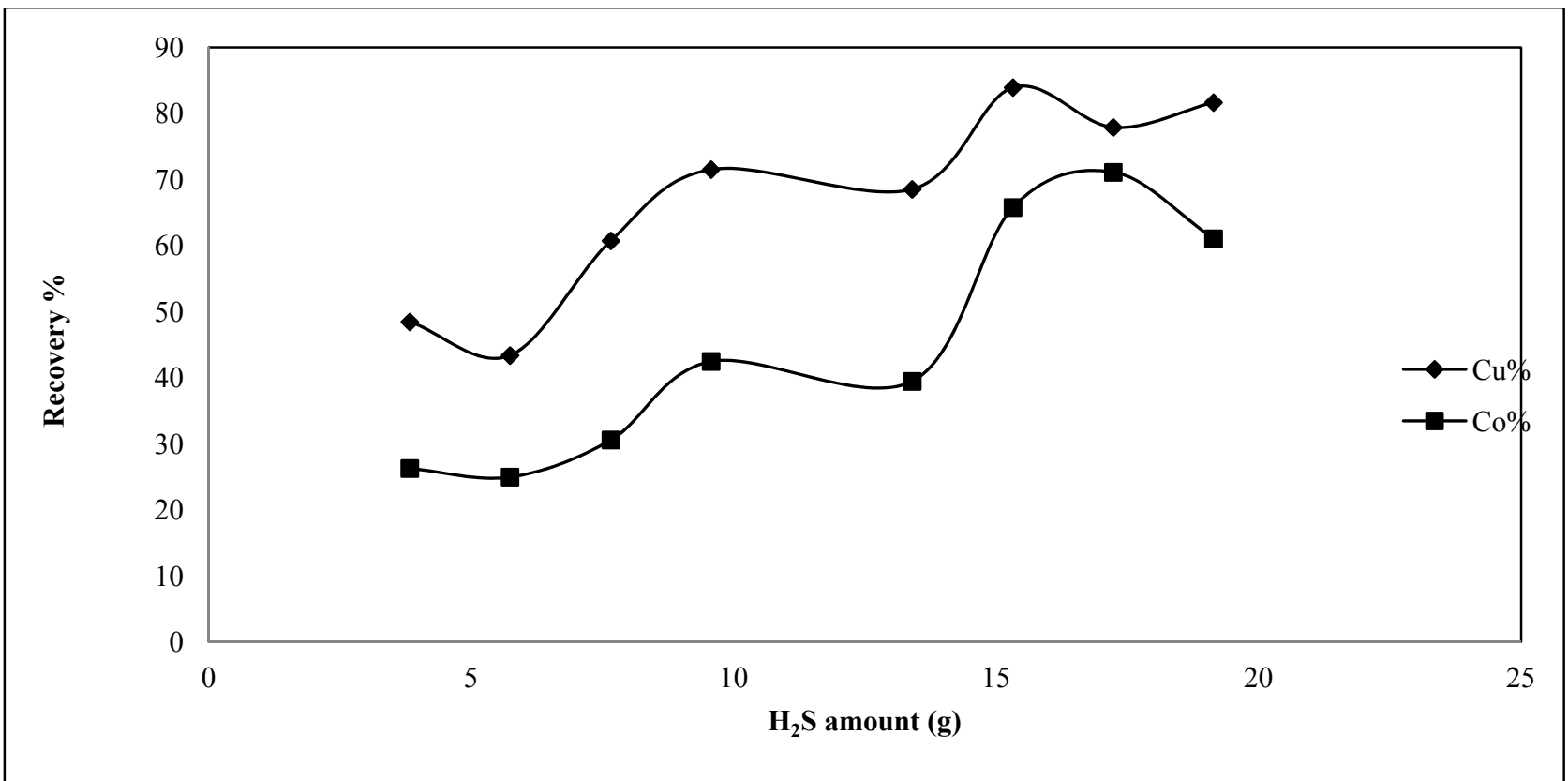

Fig. 2 The effect of sulfurization on the flotation yield of sulfurized samples (at pH 11).

Table 4 The values obtained by flotation of the sulfurized sample.

\begin{tabular}{|c|c|c|c|c|c|c|c|c|c|}
\hline \multicolumn{2}{|c|}{ Sulphurization number } & 1 & 2 & 3 & 4 & 5 & 6 & 7 & 8 \\
\hline \multicolumn{2}{|l|}{$\mathrm{pH}$} & 11.00 & 11.00 & 11.00 & 11.00 & 11.00 & 11.00 & 11.00 & 11.00 \\
\hline \multicolumn{2}{|l|}{ Froth $(\mathrm{g})$} & 22.28 & 23.93 & 26.70 & 40.51 & 37.05 & 62.67 & 47.86 & 61.23 \\
\hline \multicolumn{2}{|l|}{ Tailing (g) } & 76.03 & 76.13 & 72.70 & 59.40 & 62.32 & 37.07 & 51.96 & 38.18 \\
\hline \multirow{2}{*}{ Recovery (\%) } & $\mathrm{Cu} \%$ & 48.45 & 43.36 & 60.72 & 71.51 & 68.52 & 83.93 & 77.89 & 81.66 \\
\hline & $\mathrm{Co} \%$ & 26.26 & 24.96 & 30.57 & 42.46 & 39.46 & 65.78 & 71.10 & 61.05 \\
\hline \multirow{2}{*}{$\begin{array}{l}\text { Concentrate } \\
\text { Assay (\%) }\end{array}$} & $\mathrm{Cu} \%$ & 1.31 & 1.25 & 1.68 & 1.37 & 1.42 & 0.86 & 1.38 & 0.70 \\
\hline & $\mathrm{Co} \%$ & 0.45 & 0.42 & 0.67 & 0.64 & 0.66 & 0.44 & 0.74 & 0.43 \\
\hline \multirow{2}{*}{$\begin{array}{l}\text { Unfloated } \\
\text { Assay (\%) }\end{array}$} & $\mathrm{Cu} \%$ & 0.43 & 0.43 & 0.40 & 0.37 & 0.38 & 0.24 & 0.36 & 0.25 \\
\hline & $\mathrm{Co} \%$ & 0.38 & 0.40 & 0.57 & 0.58 & 0.59 & 0.39 & 0.28 & 0.23 \\
\hline \multicolumn{2}{|l|}{ Time (Min) } & 2.50 & 3.20 & 4.40 & 4.30 & 5.00 & 3.00 & 2.07 & 2.30 \\
\hline
\end{tabular}

activator amount. The studies were carried out at $\mathrm{pH}$ 11.0 and by using $10 \mathrm{mg}, 30 \mathrm{mg}, 50 \mathrm{mg}, 60 \mathrm{mg}, 80$ $\mathrm{mg}, 125 \mathrm{mg}, 150 \mathrm{mg}$ and $200 \mathrm{mg} \mathrm{CuSO}$ and results are given in Fig. 3.
Flotation studies were conducted using $\mathrm{CuSO}_{4}$, it can be seen that there is not a significant difference in flotation yield as activator and depressant changes. Thus, the results were not given. 


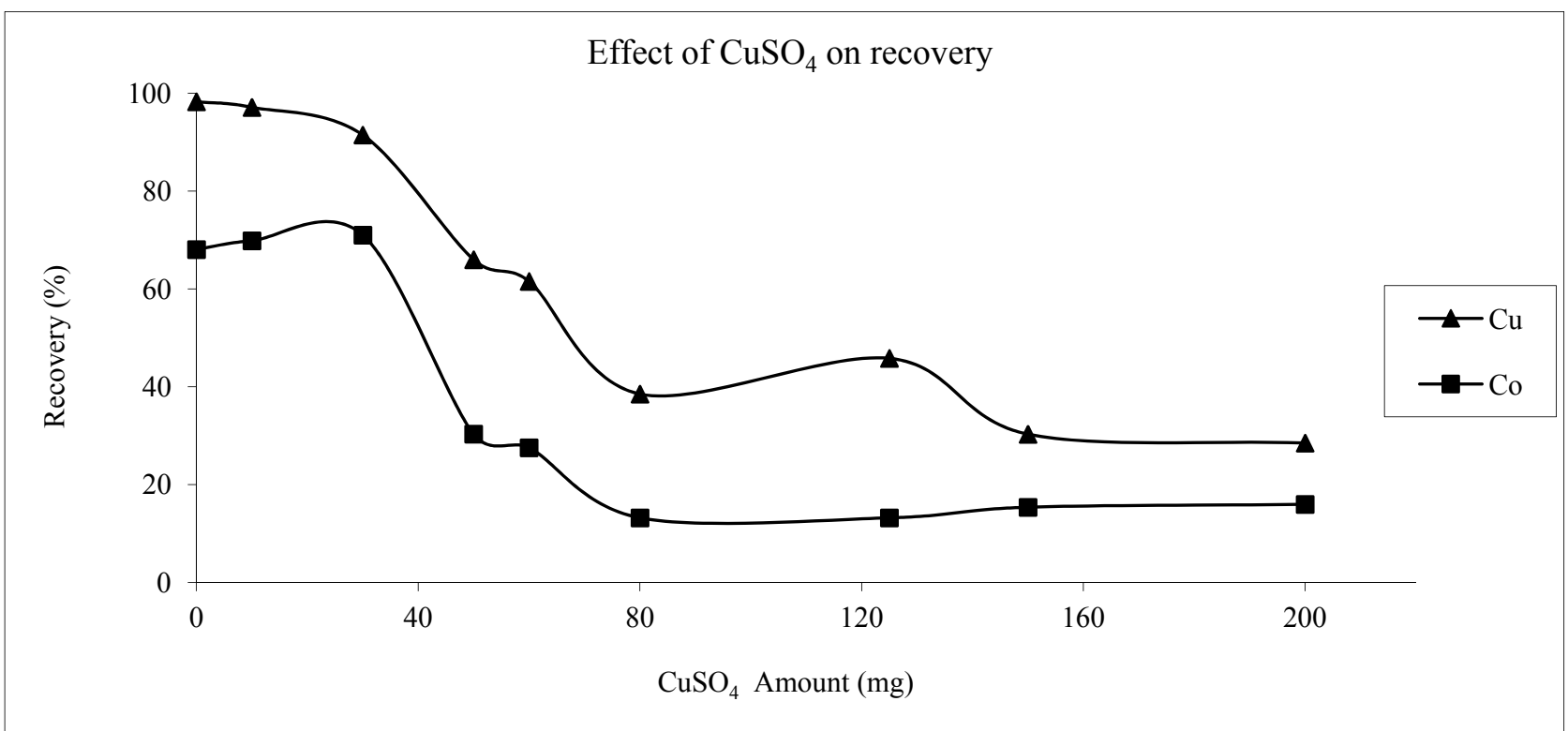

Fig. 3 The effect of activator amount on the floatability of the result obtained from seventh sulfurized samples.

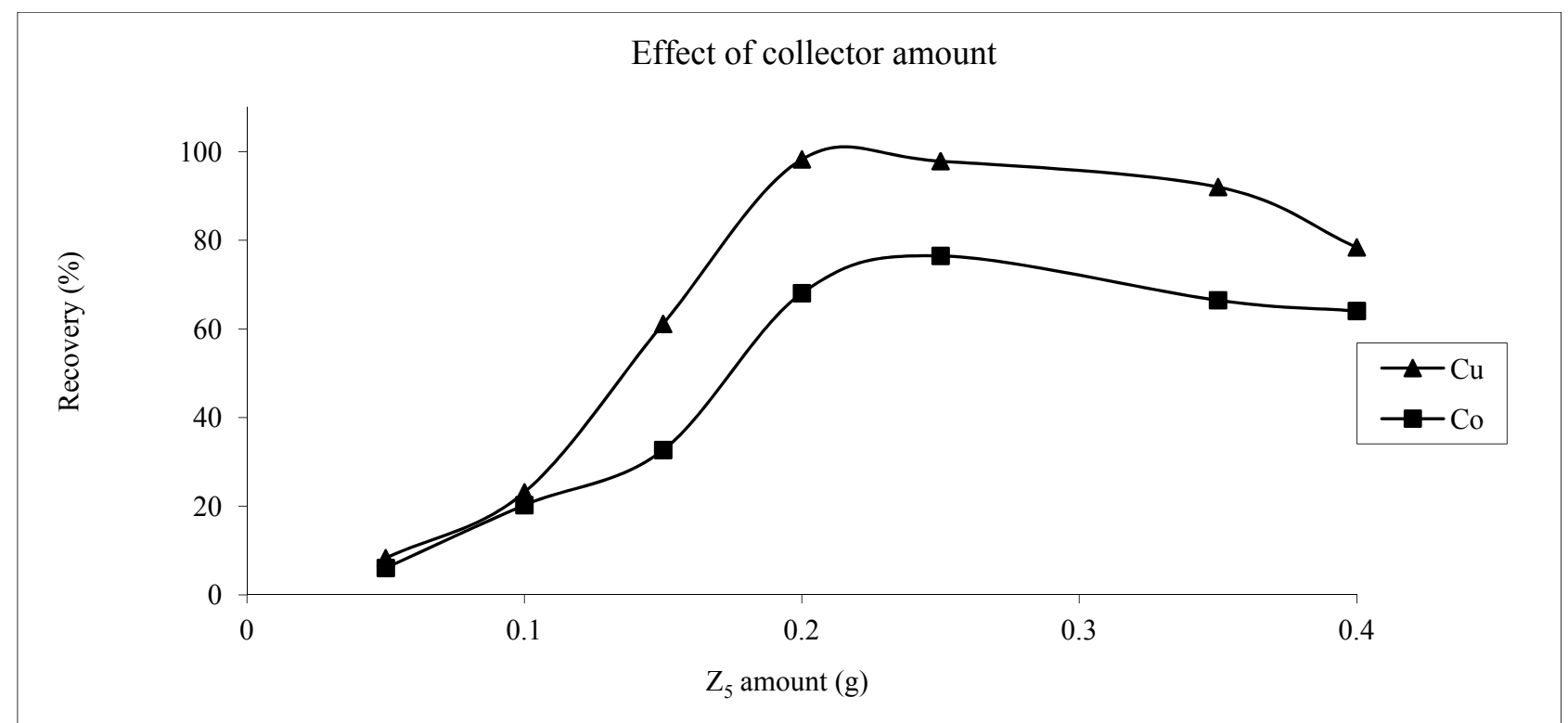

Fig. 4 The effect of collector amount on the floatability of the result obtained from a seventh sulfurized sample.

\subsection{The Effect of Collector Amount}

In this step, the flotation process on the seventh sulfurized sample was performed to test the effect of collector amount. The studies were carried out at $\mathrm{pH}$ 11.0 and by using $0.20 \mathrm{~g}, 0.25 \mathrm{~g}, 0.30 \mathrm{~g}$ and $0.35 \mathrm{~g}$ KAX (K-amyl Xanthate) and results are given in Fig. 4.

\section{Conclusions}

The findings of this study are as:
- Enrichment cannot be achieved with the flotation of original ore;

- For enrichment with flotation, it was understood that a new surface is required;

- It was determined that the efficiency increased with the flotation of the sample obtained from sulfurization of converter slag samples, sized to -100 mesh with the appropriate amount of $\mathrm{H}_{2} \mathrm{~S}$. e.g. For sulfurization of one $\mathrm{kg}$ of sieved ore, $17.23 \mathrm{~g} \mathrm{H}_{2} \mathrm{~S}+$ 
$90.00 \mathrm{~g} \mathrm{H}_{2} \mathrm{O}$ gas mixture is enough. The sulfurization was finished in 1 hour in the autoclave for $100{ }^{\circ} \mathrm{C}$;

- When the flotation of converter slag is performed at $\mathrm{pH}$ 11.00, maximum efficiency of copper and cobalt was obtained;

- Increase in the efficiency in the flotation of sulfurized samples is not only limited to the converter slag; the amount of $\mathrm{H}_{2} \mathrm{~S}$ used according to the composition of copper ore must be determined experimentally.

\section{References}

[1] Busolic, D., Parada, F., Parra, R., Sanchez, M., Palacios, J., and Hino, M. 2011. "Recovery of Iron from Copper Flash Smelting Slags." Mineral Processing and Extractive Metallurgy 120 (1): 32-6. doi: 10.1179/037195510X12772935654945.

[2] Shen, H., and Forssberg, E. 2003. "An Overview of Recovery of Metals from Slags." Waste Management 23 (10): 933-49. doi: 10.1016/S0956-053X(02)00164-2.

[3] Bellemans, I., De Wilde, E., Moelans, N., and Verbeken, K. 2017. "Metal Losses in Pyrometallurgical Operations-A Review." In Advances in Colloid and Interface Science. Elsevier. doi: 10.1016/J.CIS.2017.08.001.

[4] Yuksel, U., Tegin, I., and Ziyadanogullari, R. 2017. "Recovery of Copper and Cobalt from Copper Slags as Selective." Journal of Environmental Science and $\begin{array}{lllll}\text { Engineering } \quad A \quad 6 \quad \text { (8): 388-94. doi: } & \end{array}$ $10.17265 / 2162-5298 / 2017.08 .002$.

[5] Sarrafi, A., Rahmati, B., Hassani, H. R., and Shirazi, H. H. A. 2004. "Recovery of Copper from Reverberatory Furnace Slag by Flotation.” Minerals Engineering 17 (3): 457-9. doi: 10.1016/j.mineng.2003.10.018.

[6] Tegin, I., and Ziyadanugullari, R. 2008. "The Effect of Sulfurization Process on Flotation of Copper Ore Containing Gold and Silver." Journal of Minerals and Materials Characterization and Engineering 7 (3): 193-202. doi: 10.4236/jmmce.2008.73015.

[7] Altundoğan, H. S., and Tümen, F. 1997. "Metal Recovery from Copper Converter Slag by Roasting with Ferric Sulphate." Hydrometallurgy 44 (1-2): 261-7. doi: 10.1016/S0304-386X(96)00038-2.

[8] Anand, S., Rao, P. K., and Jena, P. K. 1980. "Recovery of Metal Values from Copper Converter and Smelter Slags by Ferric Chloride Leaching." Hydrometallurgy 5 (4): 355-65. doi: 10.1016/0304-386X(80)90025-0.

[9] Muravyov, M. I., Fomchenko, N. V., Usoltsev, A. V., Vasilyev, E. A., and Kondrat'eva, T. F. 2012. "Leaching of Copper and Zinc from Copper Converter Slag Flotation Tailings Using $\mathrm{H}_{2} \mathrm{SO}_{4}$ and Biologically Generated $\mathrm{Fe}_{2}\left(\mathrm{SO}_{4}\right)_{3}$." Hydrometallurgy 119-(1): 40-6. doi: 10.1016/j.hydromet.2012.03.001.

[10] Filippou, D., St-Germain, P., and Grammatikopoulos, T. 2007. "Recovery of Metal Values From Copper-Arsenic Minerals and Other Related Resources." Mineral Processing and Extractive Metallurgy Review 28 (4): 247-98. doi: 10.1080/08827500601013009.

[11] Ferron, C. J., and De Cuyper, J. 1992. "The Recovery of Copper and Zinc from a Sulphide Concentrate Using Sulphate Roasting, Acid Leaching and Solution Purification." International Journal of Mineral Processing $35 \quad$ (3-4): 225-38. doi: 10.1016/0301-7516(92)90035-U.

[12] Sukla, L. B. B., Panda, S. C. C., and Jena, P. K. K. 1986. "Recovery of Cobalt, Nickel and Copper from Converter Slag through Roasting with Ammonium Sulphate and Sulphuric Acid." Hydrometallurgy 16 (2): 153-65. doi: 10.1016/0304-386X(86)90040-X.

[13] Anand, S., Rao, K. S., and Jena, P. K. 1983. "Pressure Leaching of Copper Converter Slag Using Dilute Sulphuric Acid for the Extraction of Cobalt, Nickel and Copper Values." Hydrometallurgy 10 (3): 305-12. doi: 10.1016/0304-386X(83)90061-0.

[14] Ziyadanoğullari, B. 2000. "Recovery of Copper and Cobalt from Concentrate and Converter Slag." Separation Science and Technology 35 (12): 1963-71.

[15] Herreros, O., Quiroz, R., Manzano, E., Bou, C., and Vinals, J. 1998. "Copper Extraction from Reverberatory and Flash Furnace Slags by Chlorine Leaching." Hydrometallurgy $49 \quad$ (1): $87-101 . \quad$ doi: 10.1016/S0304-386X(98)00010-3.

[16] Ficeriova, J., Balaz, P., and Boldizrova, E. 2005. "Combined Mechanochemical and Thiosulphate Leaching of Silver from a Complex Sulphide Concentrate." International Journal of Mineral $\begin{array}{llll}\text { Processing } & 76 & \text { (4): } & \text { 260-5. doi: }\end{array}$ 10.1016/j.minpro.2005.01.005.

[17] Burzyńska, L., Gumowska, W., Rudnik, E., and Partyka, J. 2008. "Mechanism of the Anodic Dissolution of $\mathrm{Cu} 70-\mathrm{Co} 4-\mathrm{Fe} 14-\mathrm{Pb} 7$ Alloy Originated from Reduced Copper Converter Slag in an Ammoniacal Solution. Recovery of Copper and Cobalt." Hydrometallurgy 92 (1-2): 34-41. doi: 10.1016/j.hydromet.2008.01.009.

[18] Tümen, F., and Bailey, N. T. 1990. "Recovery of Metal Values from Copper Smelter Slags by Roasting with Pyrite." Hydrometallurgy 25 (3): 317-28. doi: 10.1016/0304-386X(90)90047-6.

[19] Aydin, F. 2002. Investigation of Ways to Evaluate Oxidized Copper Ore and Pyridine. Dicle University Institute of Science. 
[20] Aydin, I. 2001. New Practices in the Acquisition of Uranium, Nickel, Molybdenum and Vanadium from the Southeastern Asphaltite Ash. Dicle University Institute of Science.

[21] Teğin, İ. 2002. Recovery of Copper and Cobalt from Converter Slag with Flotation. Dicle University Institute of Science.

[22] Jeffery, G. H., Bassett, J., Mendham, J., and Denney, R C. 1989. Vogel's Textbook of Quantitative Chemical Analysis, Fifth edit. New York: Longman Scientific \& Technical with John Wiley \& Sons, Inc.. doi: 10.1085/jgp.25.4.523. 